\title{
STUDI EKSPLORASI PELAKSANAAN AUTHENTIC ASSESSMENT PADA IMPLEMENTASI KURIKULUM 2013 SMA DI SURAKARTA
}

\author{
Aurorana, Bakti Mulyani ${ }^{*}$, dan Budi Utami \\ Program Studi Pendidikan Kimia, FKIP,Universitas Sebelas Maret, Surakarta, Indonesia \\ *Untuk korespondensi, HP: 081393202573, e-mail: baktimulyani@gmail.com
}

\begin{abstract}
ABSTRAK
Tujuan dari penelitian ini adalah untuk mengetahui pelaksanaan Penilaian Autentik dalam pembelajaran kimia pada beberapa sekolah yang telah menerapkan kurikulum 2013 di kota Surakarta. Penelitian yang telah dilakukan merupakan penelitian deskriptif kualitatif berupa Exploratory Case Study Design. Subjek dalam penelitian ini adalah siswa kelas X IPA SMA di Surakarta tahun ajaran 2015/2016. Teknik pengumpulan data yang dilaksanakan berupa wawancara, observasi, dan analisa dokumen. Data yang diperoleh dianalisa secara kualitatif. Berdasarkan hasil penelitian, diperoleh hasil bahwa SMA A telah melaksanakan penilaian autentik berupa jurnal, tes tertulis, tes lisan, penugasan, praktek, proyek, dan produk dengan capaian berturut-turut $83,33 \%, 100,00 \%, 75,00 \%, 91,67 \%, 75,00 \%, 75,00 \%$, dan $62,50 \%$. SMA B telah melaksanakan penilaian autentik berupa jurnal, tes tertulis, penugasan, dan praktek dengan capaian berturut-turut 25,00\%, 100,00\%, 66,67\%, dan 35,00\%. SMA C telah melaksanakan penilaian autentik berupa jurnal, tes tertulis, tes lisan, penugasan, praktek, proyek, dan produk dengan capaian berturut-turut $66,67 \%, 100,00 \%, 25,00 \%, 66,67 \%, 75,00 \%, 70,00 \%$, dan $62,50 \%$.
\end{abstract}

Kata Kunci : Authentic Assessment, Deskriptif, Kurikulum 2013.

\section{PENDAHULUAN}

Pendidikan nasional berfungsi mengembangkan kemampuan dan membentuk watak serta peradaban bangsa yang bermartabat dalam rangka mencerdaskan kehidupan bangsa, bertujuan untuk berkembangnya potensi peserta didik agar menjadi manusia yang beriman dan bertakwa kepada Tuhan Yang Maha Esa, berakhlak mulia, sehat, berilmu, cakap, kreatif, mandiri, dan menjadi warga negara yang kreatif dan bertanggung jawab [1].

Untuk mencapai tujuan pendidikan yang telah dirumuskan dalam Sistem Pendidikan Nasional, Kurikulum 2013 dikembangkan atas teori pendidikan berdasarkan standar (standard-based education), dan teori kurikulum berbasis kompetensi (competency-based curriculum). Kurikulum 2013 merupakan kurikulum yang baru diterapkan pada bulan Juli tahun 2013. Kurikulum ini diberlakukan secara bertahap mulai tahun ajaran 2013-2014 melalui pelaksanaan terbatas, khususnya bagi sekolah-sekolah yang sudah siap melaksanakannya. Kurikulum ini memiliki dua karakter penting. Yang pertama adalah pembelajaran dilakukan oleh guru, yang prosesnya dilaksanakan di dalam kelas, sekolah, dan masyarakat. Dan yang kedua adalah pengalaman belajar peserta didik secara langsung dikembangkan sesuai dengan latar belakang peserta didik dan kemampuan awal yang dimilikinya [2].

Kebijakan pemerintah dalam menerapkan kurikulum 2013 mengubah beberapa poin dalam Standar Nasional Pendidikan, salah satunya adalah pada Standar Penilaian.. Pada kurikulum lama, penilaian dilakukan untuk menilai pengetahuan melalui ulangan dan ujian. Sedangkan untuk kurikulum yang baru 
ini, penilaian dilakukan secara otentik pada aspek kompetensi sikap, pengetahuan dan keterampilan berdasarkan portofolio. Dalam pelaksanaan Standar penilaian tersebut, kurikulum 2013 mempersyaratkan penggunaan penilaian autentik.

Dengan pertimbangan bahwa tidak semua guru SMA di Surakarta sudah terbiasa menggunakan penilaian autentik dalam kelasnya serta cenderung asing dengan penilaian tersebut, maka perlu diketahui seperti apa Standar Penilaian Kurikulum 2013 yang baru disusun dapat memberikan perbedaan dibanding kurikulum sebelumnya. Bagaimana instrumen penilaian disiapkan, bagaimana penilaian dilaksanakan, serta informasi apa saja yang diperoleh guru mengenai siswa lewat penilaian tersebut adalah yang menjadi fokus dalam penelitian ini. Pengamatan dan analisis dari setiap kejadian akan sangat berpengaruh terhadap penyempurnaan kurikulum tersebut ke depan.

\section{METODE PENELITIAN}

Metode penelitian yang digunakan dalam penelitian ini adalah metode penelitian deskriptif. Metode ini mencoba untuk mendeskripsikan, menjelaskan, dan menginterpretasikan kondisi dari masa sekarang. Dalam pelaksanaannya, penelitian deskriptif cenderung tidak perlu mencari atau menerangkan saling hubungan dan menguji hipotesis [3].

Dalam penelitian ini penulis menggunakan metode penelitian Eksploratory Case Study Design. Tipe Studi Kasus ini mengamati dan mencari tahu tentang suatu topik dimana terdapat sedikit sekali penelitian yang telah dilakukan sebelumnya. Tujuan dari Exploratory Case Study adalah untuk menguraikan suatu konsep, membangun sebuah model atau menyokong sebuah gagasan awal [4].

Data dikumpulkan dalam bentuk informasi mengenai pelaksanaan Penilaian Otentik (Authentic Assessment). Implementasi tersebut dilihat dari Rancangan Pelaksanaan Pembelajaran (RPP), aktivitas belajar mengajar, peran guru, peran siswa, dan instrumen evaluasi yang digunakan. Sumber data yang digunakan dalam penelitian ini adalah: dokumen, peristiwa, dan informan.

Subjek penelitian adalah siswa kelas $X$ semester I tiga Sekolah Menengah Atas di Surakarta secara purposive random sampling. Dalam hal ini dipilih berdasarkan tingkat kualifikasi SMA di Kota Surakarta yaitu SMA A (SMA paling bagus), SMA B (SMA bagus) dan SMA C (SMA kurang bagus).

Pengumpulan data dilakukan melalui tiga cara, yaitu: wawancara, observasi langsung, dan analisis dokumen. Wawancara yang dilakukan ini adalah wawancara tak berstruktur, observasi yang dilakukan merupakan observasi partisipasi pasif, serta dokumen yang di analisis di sini adalah RPP milik guru yang mengajar, instrumen evaluasi yang guru gunakan, hasil kerja siswa, dan foto maupun video.

Validasi data atau uji keabsahan data dilakukan secara kualitatif yang meliputi empat hal, yaitu uji credibility melalui triangulasi metode, uji transferability, uji dependability, dan uji confirmability [5].

Uji transferability dilakukan dengan cara penulis memberikan uraian yang rinci, jelas, sistematis dan dapat dipercaya dalam laporannya. Dengan demikian, maka pembaca menjadi jelas atas hasil penelitian ini, sehingga dapat memutuskan dapat atau tidaknya untuk mengaplikasikan hasil penelitian ini di tempat lain. Uji dependability dilakukan oleh auditor yang independen atau dosen pembimbing untuk mengaudit keseluruhan aktivitas peneliti dalam melakukan penelitian yang menunjukkan bahwa untuk memperoleh data, penelitian benar-benar telah dilakukan. Uji confirmability mirip dengan uji dependability, sehingga pengujiannya dapat dilakukan bersamaan. Menguji confirmability berarti menguji hasil penelitian dikaitkan dengan proses yang dilakukan.

Analisis tersebut dilakukan melalui tiga proses, yaitu: (1) Data Reduction (reduksi data), mereduksi data berarti merangkum, memilih hal-hal yang pokok, memfokuskan pada hal-hal yang penting, 
dicari tema dan polanya, (2) Data Display (penyajian data), yang paling sering digunakan untuk menyajikan data dalam penelitian kualitatif adalah dengan teks yang bersifat naratif, dan (3) Conclusion Drawing and Verification (menarik kesimpulan dan verifikasi) [6].

\section{HASIL DAN PEMBAHASAN}

Deskripsi pelaksanaan penilaian autentik yang telah dilaksanakan di SMA di Surakarta dijabarkan secara satu per satu sebagai berikut:

\section{Jurnal}

Penilaian autentik untuk kompetensi sikap dilaksanakan melalui 4 bentuk penilaian, yaitu penilaian diri, penilaian teman sebaya, jurnal, dan observasi. Observasi/pengamatan digunakan sebagai sumber informasi utama dan pelaporannya menjadi tanggungjawab wali kelas atau guru kelas. Sedangkan untuk teknik penilaian lainnya seperti Penilaian Diri, Penilaian Teman Sebaya, dan Jurnal menjadi penilaian penunjang.

Di sekolah yang menjadi tempat penelitian, Penilaian Diri, Penilaian Teman Sebaya, dan Observasi dilakukan oleh guru wali kelas dan guru BK, yang dilaksanakan setiap akhir semester. Sedangkan penilaian sikap yang dilaksanakan oleh guru mata pelajaran kimia adalah penilaian Jurnal.Jurnal merupakan catatan pendidik di dalam dan di luar kelas yang berisi informasi hasil pengamatan tentang kekuatan dan kelemahan peserta didik yang berkaitan dengan sikap dan perilaku[7]. Di sekolah yang menjadi tempat penelitian telah menggunakan jurnal sebagai bagian dari penilaian.

Lewat penilaian jurnal, selain mengajar guru diminta untuk memerhatikan dan mencatat sikap dan perilaku yang ditunjukkan siswa. Namun demikian , karena tugas utama guru ketika di dalam kelas adalah mengajar maka akan sangat menyulitkan jika guru diharuskan untuk mengamati siswa mereka satu per satu. Oleh karena itu untuk pengamatan terhadap siswa, guru dapat menggunakan asumsi bahwa semua siswa itu baik. Melalui asumsi tersebut, guru hanya perlu mencatat halhal yang sangat baik (positif) atau hal-hal yang sangat tidak baik (negatif) yang ditunjukkan oleh siswa. Kemudian guru mencatat perilaku yang sangat menonjol tersebut ke dalam format yang tersedia.

Format penilaian jurnal sederhana dan mudah digunakan, serta telah memuat hal-hal yang penting untuk merekam sikap siswa, yaitu apa yang mereka lakukan, kapan, dan apakah perbuatan tersebut positif atau negatif. Format jurnal penilaian sikap ini berbentuk anecdotal record yang berisi kata kunci penting terhadap sesuatu yang diamati. Catatan ini berisi narasi deskriptif singkat terhadap perilaku yang ditunjukkan siswa. Perlu diperhatikan yang dicatat di lembar penilaian adalah kata kunci penting saja, seperti contoh guru menulis "anak A jujur", "anak B aktif", atau "anak $C$ tidur di dalam kelas" dan lain sebagainya.

Pengamatan untuk penilaian jurnal ini dilakukan dari waktu ke waktu secara objektif sepanjang semester. Jika pencatatan segera dilakukan dan lengkap maka akan terlihat perkembangan siswa secara berkala. Dengan begitu guru akan lebih mengenal tentang kondisi peserta didik.

\section{Tes Tertulis}

Tes tertulis atau sering disebut paper and pencil test adalah tes yang menuntut jawaban dari peserta didik dalam bentuk tertulis sebagai representasi dari kemampuan yang dimilikinya. Tes ini memiliki kelebihan dapat mengukur kemampuan atau kompetensi peserta didik dalam jumlah besar dalam tempat yang terpisah di waktu yang sama. Objektivitasnya lebih tinggi dibanding tes lainnya karena soalnya sama dan menggunakan rubrik yang sama [7]

Secara umum terdapat dua bentuk tes tertulis, yaitu bentuk uraian (essay) dan bentuk pilihan ganda atau objektif (objective).

Dalam Kurikulum 2013 tes tertulis dilakukan pada ulangan harian, ulangan tengah semester, ulangan semester, ujian tingkat kompetensi, ujian mutu 
tingkat kompetensi, ujian nasional, dan ujian sekolah.

Instrumen yang digunakan untuk semua jenis ulangan disusun menggunakan bahasa yang tepat dan bahasa yang digunakan di dalam ruang kelas. Pertanyaan disampaikan secara sederhana, jelas, bebas dari hal-hal yang tidak penting maupun petunjuk yang tidak ada hubungannya dengan soal. Poin pertanyaan juga tidak memuat hal tentang ras, etnik, dan agama. Penggunaan bahasa dalam menyusun tes adalah hal yang harus diperhatikan karena latar belakang bahasa siswa mempengaruhi kinerja mereka ketika mengerjakan tes. Sehingga penggunaan kosakata dan sintaks dari tes yang tidak tepat, justru akan menjadi dinding penghalang bahasa bagi siswa.

Selain itu, instrumen tes tertulis memuat pernyataan yang mencerminkan tujuan. Tidak boleh ditemui soal yang dapat dimanfaatkan untuk menjawab soal yang lainnya. Waktu pengerjaan untuk mengerjakan soal telah ditentukan dengan jelas, serta penetapan poin penilaian telah terlebih dulu ditentukan sebelum tes diberikan. $\mathrm{Hal}$ ini menunjukan bahwa instrumen telah adil, dimana penilaian akhir nanti akan secara wajar terlihat sama karena menggunakan instrumen tes dan rubrik penilaian yang sama. Penampilan siswa juga akan diukur menggunakan cara yang tidak memberikan keuntungan terhadap hal-hal yang tidak berhubungan dengan pembelajaran di sekolah.

\section{Tes Lisan}

Tes lisan merupakan pemberian soal/pertanyaan yang menuntut siswa menjawab secara lisan, dan dapat diberikan secara klasikal ketika pembelajaran[8].. Tes lisan mencakup semua penilaian mengenai pembelajaran siswa yang dilaksanakan, secara keseluruhan atau sebagian besar, menggunakan kata yang diucapkan. Tes ini digunakan untuk mengungkapkan hasil belajar siswa pada aspek pengetahuan, baik secara individu maupun secara kelompok. Tes lisan dikembangkan menjadi alternatif bentuk penilaian dikarenakan ditemukannya beberapa kesulitan pada tes tertulis yang sudah sering digunakan[9]. Oleh karena itu tes lisan dapat digunakan pada ulangan harian, ulangan tengah semester, ulangan akhir semester, ujian tingkat kompetensi, ujian mutu tingkat kompetensi, dan/atau ujian sekolah.

Di sekolah yang menjadi tempat penelitian, tes lisan dilaksanakan untuk memenuhi fungsi diagnostik, yaitu untuk mengetahui pemahaman siswa terhadap kompetensi dan materi pembelajaran (assessment for learning). Pelaksanaannya adalah di bagian awal pembelajaran sebelum guru mulai mengajar materi utama untuk mengecek pengetahuan siswa mengenai materi sebelumnya, atau mencari tahu kesiapan siswa untuk memulai materi yang selanjutnya. Guru akan bertanya mengenai poin-poin penting dari materi yang sudah diajarkan di pertemuan sebelumnya. Ketika siswa yang ditunjuk tidak dapat menjawab, maka teman yang lain diminta untuk membantu, atau guru akan menunjuk siswa lainnya untuk menjawab.

Meskipun dikatakan sebagai tes lisan, tes ini tidak dilakukan terhadap semua siswa yang ada di kelas. Tes ini diberikan kepada beberapa siswa saja secara random/acak sebagai sampel dari kesiapan siswa satu kelas. Oleh karena itu tidak terdapat pencatatan hasil nilai tes lisan. Di dalam RPP juga tidak memuat adanya tes lisan. Karena tes ini memang tidak direncanakan, maka tidak ditemukan adanya instrumen soal tes lisan, rubrik penilaian, maupun pedoman penskoran.

Selain sebagai tes diagnostik, tes lisan terkadang juga digunakan di dalam tes remedial. Jika siswa terlihat telah mampu memahami pembelajaran, maka siswa boleh dinyatakan tuntas.

Dibanding tes tertulis, pelaksanaan tes lisan membutuhkan waktu yang relatif lebih lama. Dengan padatnya jadwal belajar mengajar yang ada dalam program semester, guru tidak memiliki waktu lebih untuk mengadakan tes lisan sehingga pada akhirnya guru tetap mengandalkan tes tertulis untuk memperoleh data nilai kognitif. 


\section{Penugasan}

Selain Tes Tertulis dan Tes Lisan, Penugasan merupakan teknik yang digunakan untuk melakukan penilaian pada aspek pengetahuan siswa. Penugasan adalah pemberian tugas kepada peserta didik untuk mengukur dan/atau meningkatkan pengetahuan.

Tugas yang diberikan berupa soal latihan yang harus dikerjakan, baik dari buku maupun dari guru secara langsung. Untuk tugas seperti ini biasanya tidak dinilai, hanya untuk melatih siswa memperdalam materi yang telah diberikan. Biasanya tugas ini akan dibahas secara bersama-sama di pertemuan selanjutnya, dimana ada beberapa siswa diminta untuk mengerjakan di depan, kemudian guru bersama siswa membahas hasil pekerjaan tersebut. Selain itu ada tugas membuat presentasi kelompok mengenai sifat-sifat keperiodikan dan materi lainnya. Kemudian laporan mengenai hal-hal yang mempengaruhi laju reaksi berdasarkan penelitian yang sudah dilakukan oleh siswa.

\section{Praktek}

Penilaian Unjuk Kerja merupakan penilaian tindakan atau tes praktek yang secara efektif dapat digunakan untuk kepentingan pengumpulan berbagai informasi tentang bentuk-bentuk perilaku atau keterampilan yang diharapkan muncul dalam diri peserta didik. Penilaian unjuk kerja/kinerja/praktek dilakukan dengan cara mengamati kegiatan peserta didik dalam melakukan sesuatu. Dalam pembelajaran kimia, penilaian praktek atau unjuk kerja dilakukan ketika siswa melakukan praktikum di laboratorium.

Instrumen penilaian praktek berbentuk Lembar Kerja Siswa (LKS). Siswa diminta untuk melakukan percobaan sesuai dengan prosedur percobaan yang telah diberikan oleh guru Hasil percobaan dicatat ke dalam tabel hasil pengamatan yang telah disediakan.

Penilaian praktek atau unjuk kerja dilakukan terhadap tiga keadaan; yaitu bagaimana siswa menyiapkan alat dan bahan, ketika siswa melakukan percobaan, dan bagaimanakah hasil percobaannya. Instrumen tersebut menggunakan skala penilaian 1-4, dan penskoran siswa disesuaikan dengan rubrik yang ada.

Penilaian praktek dilakukan ketika praktikum berlangsung sampai siswa memperoleh hasil dari percobaan yang mereka lakukan. Guru menilai siswa dengan cara mengamati tiap-tiap siswa dan memberi skor sesuai rubrik ketika siswa menunjukkan performansnya. Setelah praktek selesai, biasanya siswa akan berdiskusi dan dari hasil diskusi itu disusun ke dalam laporan praktikum individu. Laporan praktikum yang diperoleh dapat dikategorikan sebagai produk tertulis siswa dan dapat menjadi sumber data bagi penilaian produk.

Dalam pelaksanaannya, tidak semua materi pembelajaran kimia dapat menggunakan penilaian ini. Nilai yang diperoleh pun diambil dari hasil kerja yang dilakukan siswa sehingga dapat membuat siswa yang kurang mampu akan merasa minder. Jumlah siswa dalam kelas dapat menjadi hambatan, karena jika siswa banyak guru kesulitan untuk membimbing, mengamati, dan menilai mereka. Keterbatasan waktu juga bisa menjadi masalah karena penilaian ini harus dilakukan secara penuh dan lengkap. Selain itu keterbatasan tempat juga memberi andil dalam sulitnya melakukan penilaian ini.

\section{Proyek}

Penilaian proyek merupakan kegiatan penilaian terhadap suatu tugas meliputi kegiatan perancangan, pelaksanaan, dan pelaporan, yang harus diselesaikan dalam periode/waktu tertentu [7].

Penilaian Proyek menggunakan instrumen yang dapat disebut juga dengan petunjuk teknis pelaksanaan. Petunjuk teknis digunakan untuk memperlancar pelaksanaan penilaian proyek. Di dalam petunjuk tersebut tercantum judul kegiatan, tujuan, dan langkah kegiatan yang harus siswa lakukan. Petunjuk teknis yang baik memuat diantaranya adalah tercantum nama proyek, rentang waktu pengerjaan 
tugas, sistematika laporan, aspek yang dinilai, serta jenis tugas apakah bersifat individual atau kelompok.

Untuk melaksanakan penilaian proyek dibutuhkan adanya suatu standar acuan dalam menentukan kualitas penilaian proyek. Acuan tersebut disusun dalam bentuk instrumen penilaian yang bisa berupa daftar cek atau skala penilaian, serta dilengkapi dengan rubrik. Rubrik penilaian berisi aspek-aspek yang akan dinilai dari proyek yang disertai dengan pedoman penskoran. Penilaian untuk proyek mencakup tiga hal yaitu perencanaan, pelaksanaan, dan pelaporan proyek yang dapat dilihat di rubrik di bawah ini.

Pembelajaran berbasis proyek ini baik untuk digunakan sebagai strategi alternatif penilaian karena siswa harus secara aktif mendemonstrasikan apa yang mereka ketahui dan apa yang mereka dapat lakukan. Pembelajar membawa pengetahuan dasar mereka, hal yang baru saja dipelajari, dan kemampuan yang relevan untuk memecahakan permasalahan yang autentik dan realistik. Melalui penilaian proyek ini, guru akan memiliki banyak kesempatan untuk mengamati hal tersebut. Penilaian ini membiarkan siswa untuk menunjukkan kemampuannya sambil bekerja secara mandiri. Melalui proyek ini juga dapat mengembangkan kemampuan siswa untuk bekerja bersama teman-temannya dalam mendapat informasi untuk memecahakan masalah sehingga dapat membangun kerjasama dan kemampuan berkelompoknya.

Namun demikian, penilaian proyek juga menemui permasalahan. Untuk proyek yang dikerjakan secara berkelompok, guru akan sulit memantau kinerja siswa. Terdapat siswa yang kurang bertanggungjawab yang hanya titip nama tetapi tidak terlibat dalam pengerjaan proyek sehingga proyek ini akan didominasi oleh siswa yang mampu bekerja dan siswa pandai. Selain itu karena sifat pelaksanaannya yang jangka panjang, penilaian ini akan menghabiskan banyak waktu dalam proses belajar mengajar. Ditambah pula jika semua guru memberi tugas masing- masing, hal itu akan memberatkan bagi siswa. Namun demikian jika guru-guru dapat berkolaborasi, karena sifat penilaian proyek ini adalah multidimensional, maka hal tersebut dapat mengurangi beban siswa. Siswa pun akan memahami bahwa ilmu-ilmu yang mereka pelajari di sekolah, sekalipun tampak begitu berbeda, sebenarnya saling berkaitan dan bermanfaat bagi kehidupan dunia nyata.

\section{Portofolio}

Portofolio merupakan penilaian berkelanjutan berdasarkan kumpulan informasi berupa karya siswa yang bersifat reflektif-integratif yang menunjukkan perkembangan kemampuan siswa dalam satu periode tertentu[13]. Portofolio dibangun dengan cara yang dinamis, dimana item-item dikumpulkan, direview, dan diperbaiki oleh guru bersama siswa dalam suatu periode waktu. Berdasarkan hasil penilaian tersebut, guru dan siswa dapat menilai perkembangan kemampuan siswa dan terus melakukan perbaikan. Sehingga, portofolio dapat memperlihatkan perkembangan kemajuan belajar siswa melalui karyanya.

Sekalipun sudah beberapa tahun diperkenalkan, penilaian portofolio termasuk hal yang masih asing bagi guru. Di sekolah-sekolah yang digunakan sebagai tempat penelitian belum dapat melaksanakan penilaian portofolio secara maksimal. Sementara ini, penilaian ini masih dilaksanakan secara sederhana berupa mengumpulkan lembaran-lembaran kertas tugas yang bermacam-macam.

Meskipun ada banyak manfaat yang dapat diperoleh dari penilaian ini, banyak hal yang harus diperhatikan serta hambatan yang harus diatasi untuk mendesain sebuah portofolio. Dan hambatan terbesar itu adalah terbatasnya waktu yang dimiliki oleh guru untuk melaksanakan penilaian tersebut. Selain tugas utama mengajar, guru juga memiliki banyak tugas adminstratif yang harus dipenuhi. Waktu guru di luar jam mengajar pada akhirnya digunakan untuk memenuhi tugas administratif 
sehingga waktu untuk melaksanakan penilaian secara lengkap seperti yang diharapkan di dalam kurikulum 2013 menjadi sempit dan tidak kondusif. Pada akhirnya guru terpaksa tidak melaksanakan dan meninggalkan penilaian tersebut.

\section{Produk}

Penilaian produk merupakan teknik penilaian yang termasuk ke dalam Performance-based assessment, yaitu penilaian berdasarkan hasil pengamatan penilai terhadap aktivitas siswa sebagaimana yang terjadi.

Untuk pelaksanaan penilaian produk yang dilakukan di sekolah yang menjadi tempat penelitian, penilaian ini sudah dilakukan. Akan tetapi penilaian produk masih terbatas pada produk yang dimanfaatkan untuk kalangan institusi sekolah seperti contohnya produk tertulis seperti karya ilmiah atau produk visual seperti media pembelajaran. Produk tersebut bermanfaat bagi siswa karena mampu membantu dan mendukung pembelajaran mereka, namun produk tersebut belum dikatakan autentik karena produk belum dapat dimanfaatkan untuk kehidupan nyata.

Kelebihan dari penilaian produk adalah guru dapat menilai kreatifitas siswa berkaitan dengan daya cipta dan kompetensi yang mereka miliki. Kompetensi peserta didik dapat diketahui secara obyektif. Siswa dapat menerapkan ilmu yang mereka peroleh secara langsung ke dalam pengalaman yang nyata sehingga mereka merasa bahwa ilmu yang mereka miliki berguna.

Disamping keunggulannya, penilaian produk juga memiliki kekurangan. Kriteria yang digunakan untuk menilai suatu produk harus diidentifikasikan dari awal karena kepraktisan atau kegunaan juga harus diperhatikan. Guru harus lebih berhatihati ketika menilai produk yang dibuat oleh siswa, dan dapat memberi jaminan penilaian mereka tidaklah terlalu terpengaruh oleh variabel ekstra seperti kerapian atau lainnya. Selain itu, tidak semua kompetensi dapat dibuat karya nyata, terutama untuk mata pelajaran yang memiliki banyak konsep abstrak seperti contohnya pembelajaran kimia. Kemampuan fisik peserta didik sebagai penunjang untuk memenuhi penilaian ini juga tidaklah sama. Permasalahan lain yang timbul adalah guru tidak mengetahui pekerjaan siapakah produk yang sudah jadi atau siapa saja kah yang berkontribusi terhadap produk akhir.

Penilaian autentik telah dilaksanakan dengan sangat baik di SMA di Surakarta yang telah menggunakan Kurikulum 2013 dalam pembelajarannya. Baik dari pihak guru, sekolah, maupun pemerintah, telah bekerja sama agar pelaksanaan penilaian autentik dapat berjalan maksimal. Penilaian adalah komponen yang sangat penting dari proses belajar mengajar. Tanpa adanya penilaian kelas yang efektif, sangat sulit untuk mengetahui apakah siswa telah mencapai target yang telah ditentukan. Apa yang dinilai, bagaimana cara menilai dan mengevaluasi, lalu bagaimana mengkomunikasikan hasilnya, memberikan pesan yang sangat jelas kepada siswa tentang apa yang berharga untuk dipelajari, bagaimana mempelajarinya, kualitas apakah yang paling penting, serta seberapa baik hasil yang mereka harapkan dapat mereka capai. Dengan berbagai macam pertimbangan, guru dapat mempersiapkan diri untuk mengembangkan dan menggunakan salah satu teknik penilaian kelas yang dapat memberikan keadilan, kevalidan, dan informasi yang bisa dipercaya yang akan meningkatkan pembelajaran. Tabel 1 merupakan capaian dari penilaian yang guru pilih dan laksanakan di dalam pembelajaran kimia. 
Tabel 1. Capaian Hasil Analisis terhadap Penilaian Autentik yang Dipilih dan Dilaksanakan pada Pembelajaran Kimia.

\begin{tabular}{clccc}
\hline No & \multicolumn{1}{c}{ Jenis Penilaian } & $\begin{array}{c}\text { \% capaian } \\
\text { SMA A }\end{array}$ & $\begin{array}{c}\text { \% capaian } \\
\text { SMA B }\end{array}$ & $\begin{array}{c}\text { \% capaian } \\
\text { SMA C }\end{array}$ \\
\hline 1 & Observasi & - & - & - \\
2 & Penilaian Diri & - & - & - \\
3 & Penilaian teman sebaya & - & - & - \\
4 & Jurnal & 83.33 & 25.00 & 66.67 \\
5 & Tes tulis & 100.00 & 100.00 & 100.00 \\
6 & Tes Lisan & 75.00 & $\mathrm{x}$ & 25.00 \\
7 & Penugasan & 91.67 & 66.67 & 66.67 \\
8 & tes Praktek & 75.00 & 35.00 & 75.00 \\
9 & Proyek & 75.00 & $\mathrm{x}$ & 70.00 \\
10 & Produk & 62.50 & $\mathrm{x}$ & 62.50 \\
11 & Portofolio & $\mathrm{x}$ & $\mathrm{x}$ & $\mathrm{x}$ \\
\hline
\end{tabular}

Keterangan tabel

- $\quad=$ Pelaksanaan jenis penilaian tidak dilakukan oleh guru mata pelajaran.

Dilakukan oleh guru walikelas/BK.

$\mathrm{x}=$ Guru memilih tidak menggunakan jenis penilaian dalam pembelajaran kimia

\section{KESIMPULAN}

Sekolah Menengah Atas di Surakarta telah menerapkan penilaian autentik ke dalam teknik penilaian yang mereka lakukan. Bentuk penilaiannya antara lain tes tulis, penugasan, penilaian diri, penilaian teman sebaya, observasi, jurnal, praktek, proyek dan produk.

Tes tertulis telah dilaksanakan meliputi pelaksanaan Ulangan Harian, Ulangan Tengah Semester, dan Ulangan Akhir Semester. Penugasan telah dilakukan dalam bentuk tugas kelompok mengamati keadaan lingkungan sekitar. Penugasan dalam bentuk lain adalah mengerjakan soal-soal yang diberikan oleh guru. Penilaian Diri dan penilaain teman sebaya telah dilakukan untuk menilai capaian kompetensi sikap sosial dan sikap spiritual siswa yang pelaksanaanya dilakukan pada akhir semester. Observasi telah dilakukan oleh guru pada waktu-waktu menjelang akhir semester. Jurnal telah dilakukan oleh guru secara autentik yang mencatat sikap dan perilaku yang ditunjukkan oleh siswa sepanjang semester. Penilaian Praktek / Unjuk Kerja telah dilakukan yang pelaksanaannya disesuaikan dengan kompetensi dasar mata pelajaran kimia yang membutuhkan adanya praktek untuk menunjang pembelajaran. Penilaian Proyek telah dilakukan dalam bentuk siswa merancang percobaan sederhana setelah mengamati keadaan lingkungan sekitar. Serta Penilaian Produk telah dilakukan dalam bentuk produk tertulis (laporan praktikum, rangkuman materi) dan produk visual (media pembelajaran bentuk molekul dari kertas).

Tes lisan dan protofolio belum dilakukan secara maksimal. Tes lisan dilakukan terhadap beberapa siswa hanya untuk memenuhi fungsi diagnostik mengenai kesiapan siswa untuk memulai pembelajaran selanjutnya. Sedangkan untuk penilaian portofolio masih kurang maksimal dilakukan dikarenakan adanya kekurangan waktu yang diperlukan oleh guru untuk merancang portofolio, serta kesulitan untuk mendokumentasikan hasil karya siswa.

\section{UCAPAN TERIMA KASIH}

Ucapan terima kasih diberikan kepada Dra. Harminingsih, M.Pd., Drs. Sutikno M.M., serta Drs. H.M. Haryadi Purwanto, M.Ag., selaku Kepala Sekolah yang telah mengizinkan penulis untuk mengadakan penelitian. Penulis juga 
mengucapkan terimakasih kepada ibu Endang Siwi, S.Pd., ibu Widiastututi, S.Pd. M.M., serta Dra. Nurul Hasanah selaku guru mata pelajaran kimia yang telah membantu penulis memperoleh informasi.

\section{DAFTAR RUJUKAN}

[1] Pemerintah Republik Indonesia. (2003). Undang-Undang Republik Indonesia Nomor 20 Tahun 2003 Tentang Sistem Pendidikan Nasional' Indonesia.

[2] Kemendikbud. (2013). Peraturan Menteri Pendidikan Pendidikan dan Kebudayaan Republik Indonesia Nomor 69 Tahun 2013 Tentang Kerangka Dasar dan Struktur Kurikulum Sekolah Menengah Atas/Madrasah Aliyah. Indonesia.

[3] Zuriah, N. (2005). Metodologi Penelitian Sosial dan Pendidikan Teori-Aplikasi. Jakarta: Bumi Aksara.
[4] Yin, R.K. (1994). Case Study Research: Design and Methods (2nd edition). California: Sage Publication.

[5] Sugiyono. (2009). Metode Penelitian Kuantitatif Kualitatif dan $R \& D$. Bandung: Alfabeta.

[6] Huberman, A. M. \& Miles, M. B. (1984). Qualitative Data Analysis, A Sourcebook of New Method. California: SAGE Publication, Inc.

[7] Kunandar. (2013). Penilaian Autentik Kurikulum 2013. Jakarta: Rajawali Press.

[8] Direktorat Jenderal Pendidikan Dasar dan Menengah. (2017). Panduan Penilaian untuk Sekolah Menengah Atas. Jakarta: Kemendikbud.

[9] Joughin, G. (2010). A Short Guide to Oral Assessment. Leeds: Leeds Met Press. 